\title{
GIS technologies used in zoning agricultural land for optimizing regional land use
}

\author{
Eleonora Tsoraeva ${ }^{1, *}$, Sirunik Mezhyan ${ }^{1}$, Marina Kataeva ${ }^{2}$, Ludmila Hugaeva ${ }^{2}$, and \\ Tatyana Rogova ${ }^{2}$ \\ ${ }^{1}$ Kuban State Agrarian University named after I.T. Trubilin, 350044 Krasnodar, Russia \\ ${ }^{2}$ Gorsky State Agrarian University, 362040 Vladikavkaz, Russia
}

\begin{abstract}
The paper discusses the main definitions and advantages of using GIS technologies in land management. The results of the implementation of the use of GIS technologies in agriculture are given, which will greatly facilitate the work of specialists. Work with various maps, digitization and explication of lands using the MapInfo geoinformation product is clearly presented. High-quality introduction of new technologies is necessary in Russia.
\end{abstract}

\section{Introduction}

For the effective development of agricultural production, it is necessary to introduce highly efficient technologies for collecting and processing information. As the world experience shows, information technologies can be of significant help in solving numerous problems. The main purpose of GIS in land management is the creation of digital maps and plans of the area. The use of GIS technologies allows for a more complete assessment of land resources. They can be most objectively assessed when analyzing geo-information about the quality and value of specific land plots [1].

It should be noted that land management includes a system of state, economic, engineering and legal measures aimed at the rational use of lands and their protection. Many geographic information products have made it much easier to carry out land surveying. The land management digitalization project is a complex systemic task that affects the content of land management and the entire land management system of the country. Such a project certainly requires fundamental and structural changes, changes in the logic of the relationship between governmental and departmental structures with the designation of a single territorial reference [2,3]. However, the digitalization of land management cannot be carried out without creating a single integrated information system.

\section{Methodology}

Territory zoning is a form of land management, the result of which is the establishment of limits for the exploitation of land plots, possible means and methods of their use, depending

\footnotetext{
* Corresponding author: elionora@list.ru
} 
on belonging to a particular zone. In the current Land legislation, various types of zoning are mentioned: urban planning, environmental, functional, zoning carried out by establishing zones with special conditions for the use of territories, etc.

Depending on the priority goals of territorial development in the scientific literature, it is proposed to distinguish three types of zoning $[4,5]$ :

1) permissive and restrictive (urban planning, land and legal);

2) restrictive and ecological;

3) organizational and managerial (functional, evaluative) $[6,7]$ :

Several basic approaches to the functional zoning of agricultural lands have developed

- agroecological zoning is carried out on the basis of an agroecological approach, as a result of which agricultural lands are delineated in accordance with their levels of suitability for crop cultivation;

- ecological and landscape zoning, as well as agro-landscape zoning, which is based on the integration of ecological and landscape approaches;

- on the basis of the ecological and economic approach, such types of zoning as ecological and economic are being developed; ecological and economic, ecological and functional, the essence of which is to take into account both natural-ecological and socioeconomic factors of agricultural natural resource management;

The use of the MapInfo geoinformation product gives great opportunities for information processing, for finding specific errors. Working in the MapInfo geographic information product, it is possible to initially open several layers of different maps in one window. For example, a map with a base of boundaries of land plots of a district together with a map of the boundaries of a settlement, cadastral plans of territories, orthophotomaps of the district and the original border of a rural settlement (Fig. 1).

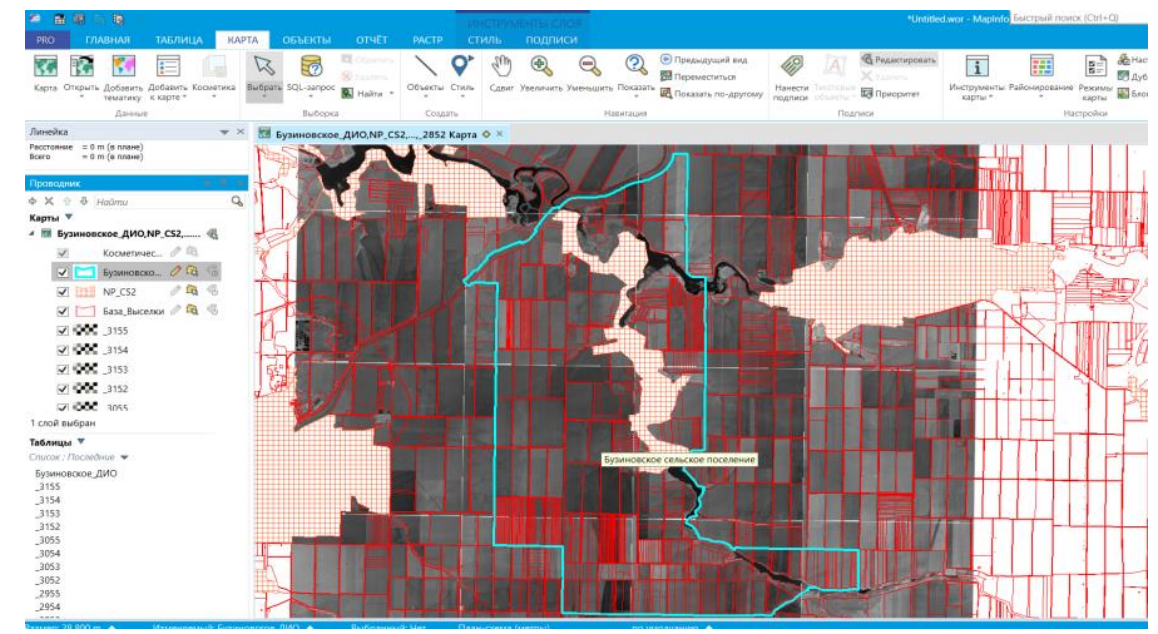

Fig. 1. Fragment of work with a satellite image using the MapInfo GIS technology.

These advantages allow performing work in the shortest possible time. MapInfo allows geteting information about the location by address or name, finding the intersection of streets, borders, performing automatic and interactive geocoding, putting objects from the database on the map. The presentation of information in the system can be in the form of tables, maps, diagrams, text references. Only the relevance, accuracy and completeness of the source data can ensure the effective use of information technology in agriculture. The peculiarity of the use of information technology in agriculture is that almost all the data used are geographically referenced. 


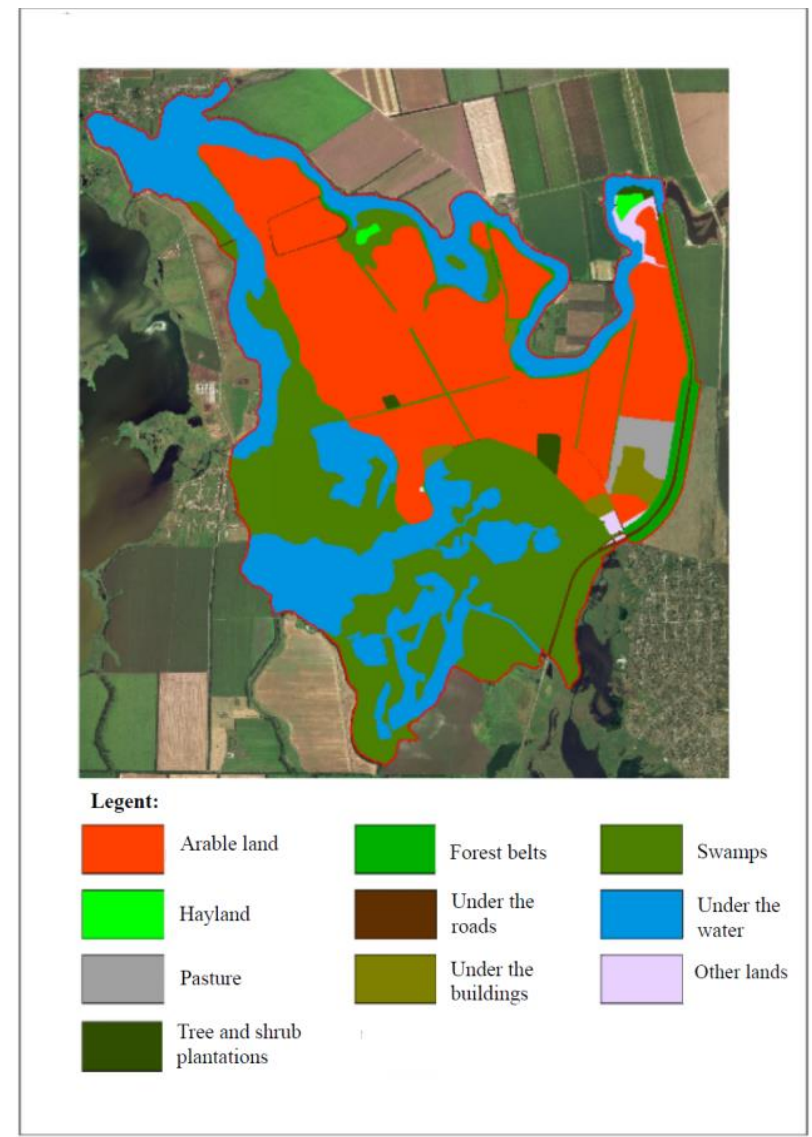

Fig. 2. Fragment of digitization of agricultural lands using satellite imagery in MapInfo GIS technology.

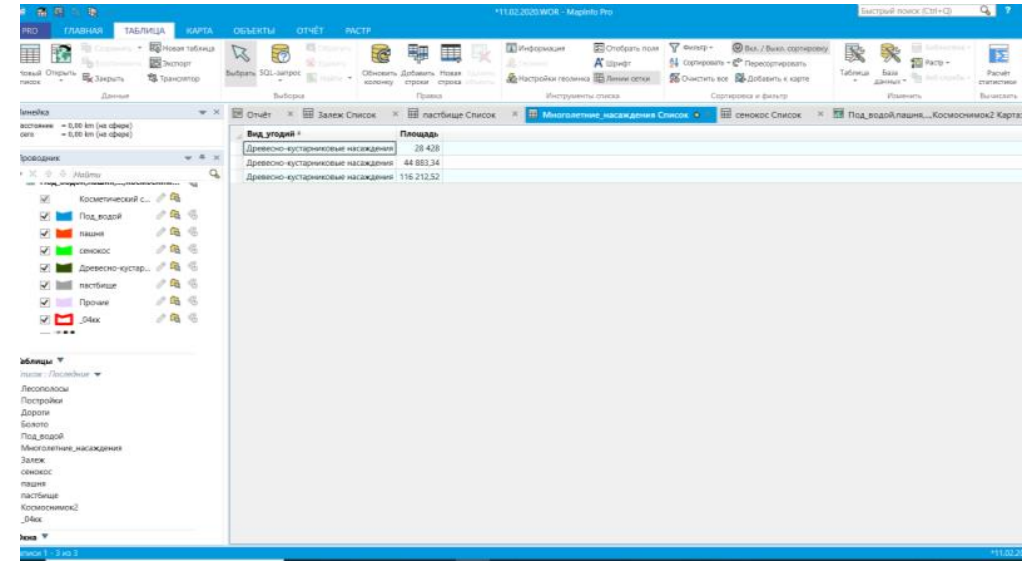

Fig. 3. An example of filling in tables in MapInfo GIS technology .

MapInfo GIS program allows reproducing the digitization of land plots (Fig. 2). For this, layers are created, each of which corresponds to a separate type of land. After digitization, the area is determined for each type of land. In accordance with this, it is 
possible to draw up an explication of the lands of all plots within the boundaries of the cadastral quarter (Fig. 3).

Within the boundaries (lines) of urban and rural settlements, zones of agricultural use are distinguished:

1. arable lands

2. gardens

3. vineyards

4. vegetable gardens

5. haylands

6. pastures

7. plots occupied by agricultural buildings, structures, facilities.

The territories of such zones can be used for farming until the moment the type of their use changes in accordance with the master plan and building rules.

\section{Results}

Thanks to GIS technologies, we are able to work with maps, diagrams and graphs, identify the main problems and develop their solution. Regular use of technology will provide a wide range of users with access to automation tools for land management design based on information about agricultural land and rural areas. This will ensure the implementation of a long-term strategy for structuring the land market, the creation and subsequent use of the system will reduce the costs of agricultural producers by ensuring the optimal inclusion of such technologies and technological complexes into the production system when developing land management projects. The development and implementation of digital technologies will open a strategic area of the automation and optimization of land management design processes and the implementation of rural development projects. GIS technology data systems should contain such information as boundaries, agricultural land and crop areas, and soil fertility indicators.

The introduction of such technologies and programs is ensured by state and local authorities:

- legally complete information about projects and their developers;

- instruments for automated implementation of the powers of these authorities and companies within the framework of land management tasks;

- instruments for monitoring and control of the implementation of land management design solutions agreed and approved in the prescribed manner.

Initial information and results of land surveying work should be stored in databases and displayed on a digital cartographic basis. This will significantly facilitate and speed up the processes of land management design, ensure its high quality in modern conditions, as well as ensure the expertise of projects, monitoring of their implementation and control by the authorities and stakeholders $[15,16]$.

The formation of a database and the creation of electronic maps of land-managed agricultural organizations should include the following operations:

- creation of projects for the organization of the territory of agricultural landscapes based on CALMDS;

- verification of documents;

- monitoring of the qualitative condition and quantitative characteristics of lands;

- economic analysis of options for organizing the territory;

- provision of information.

Concepts and programs of land use and protection have ceased to be developed, taking into account land management principles at the federal, regional and municipal levels. The required land management projects are not being designed. With this approach, the 
territorial system of land use planning and their protection is violated, negative and degradation processes of land develop, agricultural enterprises and producers go bankrupt and cease to exist $[8,9]$. All processes and land transformations must be developed on the basis of land management design documentation. For full-fledged monitoring and comprehensive analysis of all these issues, it is necessary to use modern technologies: geographic information systems (GIS), land information systems (LIS), computer-aided land management design systems (CALMDS), unmanned aerial vehicles (UAVs).

\section{Conclusion}

Zoning of agricultural lands is aimed at detailing the legal regime of land plots from the composition of lands of this category through the normative consolidation of the specifics of their use and protection, the rights and obligations of participants in land legal relations, as well as possible restrictions on these rights.

The use of digital land management systems will allow:

1. Creating an information computer system for assessing the quality and location of agricultural land.

2. Completing the state cadastral registration of all agricultural land plots.

3. Developing agricultural land protection measures to improve the land use efficiency.

The peculiarity of these systems is that they allow integrating, maintaining and jointly analyzing a variety of types of spatially distributed indicators and descriptive data [10-12]. These systems are used to create and maintain cadastres of land and water bodies, property registers, environmental and weather monitoring, emergency management, assessment of industrial risks, analysis of the relationship of various factors affecting crop productivity and in many other applications based on geographically distributed information $[13,14]$.

Nevertheless, GIS is a combination of electronic maps, databases and tools for their maintenance and analysis. The capabilities and flexibility of these systems make them applicable both nationwide and at the farm level.

Thus, the use of digital technologies is an instrumental environment for land management design based on the use of relevant data on a specific territory. The system provides the land surveyor with design tools that allow him to independently enter the actual data or receive it from various sources, make design decisions and obtain a threedimensional digital model of the project.

\section{References}

1. Boraev A.A., Rogova T.A. Efficiency of using agricultural land in the Alagir region of the North Ossetia-Alania. In the collection: Scientific achievements for agriculture. Proceedings of the All-Russian scientific and practical conference (virtual conference). 2017.P. 31-34.

2. Mezhyan S.A., Tsoraeva E.N. On the state cadastral registration of land. In the collection: Land management, real estate cadastre and monitoring of land resources. Proceedings of the international scientific and practical conference. Ulan-Ude, 2020.P. 35-39.

3. Mezhyan S.A., Tsoraeva E.N. Drawing up a map of the lands of the cadastral quarter in the Mapinfo Pro software. Science Diary [Dnevnik Nauki]. 2020. No. 7 (43). P. 17.

4. Simonova L., Dzobaeva D.A., Rogova T.A. Monitoring of the use of agricultural land by the Irbis APC in the Pravoberezhny District of the Republic of North OssetiaAlania. In the collection: Vestnik of scientific works of young scientists, graduate students, undergraduates and students of the FSBEI HE "Gorsky State Agrarian 
University”. Editor-in-chief: V.Kh. TEMIRAEV. Gorsky State Agrarian University, Vladikavkaz, 2018.

5. Pekh A.A., Khugaeva L.M., Kataeva M.V. Effectiveness of the application of the data of the state cadastre of real estate in the territory of the municipality of the city of Beslan, RNO-Alania. In the collection: Geodesy, land management and cadastres: problems and development prospects, dedicated to the 100th anniversary of Soviet geodesy and cartography. Collection of proceedings of the I International scientific and practical conference. 2019. P. 320-324.

6. Pekh A.A., Khugaeva L.M., Kataeva M.V. Problems of cadastral work in the Republic of North Ossetia - Alania. In the collection: Geodesy, land management and cadastres: problems and development prospects, dedicated to the 100th anniversary of Soviet geodesy and cartography. Collection of proceedings of the I International scientific and practical conference. 2019.P. 325-328.

7. Kozyreva A.Z., Salbieva V.V., Rogova T.A. Vestnik of scientific works of young scientists, graduate students, undergraduates and students of the FSBEI HE "Gorsky State Agrarian University”. Gorsky State Agrarian University. Vladikavkaz, 2016.P. 47-50.

8. E. Tsoraeva. Problems of rational use and soil protection, Collection of articles on materials 73th scientific-practical conference of teachers, pp. 247-248, (2018)

9. E. N. Stratinskaya Changes in the humus state of ordinary chernozems during cyclic irrigation. Scientific journal of the Russian Research Institute of Melioration Problems 1(1), 7 (2011).

10. Stratinskaya E.N. Changes in soil properties with a decrease in water load. Melioration and water management 2, 33-35 (2010).

11. Sekisov, A.N., Ovchinnikova, S.V., Norenko, M.S., Matevosyan, V.S. IOP Conference Series: Materials Science and Engineering 913(4), 042051 (2020)

12. Sekisov, A., Ovchinnikova, S., Grebneva, V., Chernyshova, M. IOP Conference Series: Materials Science and Engineering 913(4), 042035 (2020).

13. Kalinichenko, M.Y., Stojanov, N.I., Abornev, D.V., Ovchinnikova, S.V. IOP Conference Series: Materials Science and Engineering 905(1), 012034 (2020). https://doi.org/ 10.1088/1757-899X/905/1/012034

14. S. Ovchinnikova, D. Abornev, M. Kalinichenko, A. Kalinichenko, A. Sekisov Advances in Intelligent Systems and Computing, Springer 1259 (2021).-Pp.-601-610. https://doi.org/10.1007/978-3-030-57453-6_57

15. S. Ovchinnikova, et al. E3S Web of Conferences 157, 06028 (2020). https://doi.org/10.1051/e3sconf/202015706028

16. Tsoraeva E.N. Omsk Scientific Bulletin. Series: Society. History. Modernity 5(3), 141146 (2020).

17. Tsoraeva E.N. Problems of violation of land legislation in the Krasnodar Territory. Vestnik of the Kyrgyz-Russian Slavic University 19(3), 114-116 (2019) 